\title{
Effects of Flue-curing on Cigarette Smoke Condensates Mutagenicity*
}

\author{
by \\ André Morin, Nicole Poirier, David Préfontaine, and Martine Lacasse \\ Imperial Tobacco Canada Limited, 3711 St-Antoine Street West, Montreal, QC, H4C 3P6, Canada
}

\section{SUMMARY}

Flue-curing is a post harvest conditioning process which strongly affects the tobacco leaf chemistry, and consequently the chemical properties of tobacco smoke. Several studies identified the major changes in tobacco chemistry occurring during flue-curing. It is not known how flue-curing contributes to changes in bioactivity of cigarette smoke condensate (CSC). In this study, tobacco leaves collected throughout the twelve days of flue-curing were used to prepare cigarettes that were smoked to generate CSC samples. The assessment of mutagenicity was performed using the Bacterial Reverse Mutation / Ames test with Salmonella typhimurium TA98 in the presence of S9 metabolic activation. CSC from cured leaves were significantly more mutagenic than CSC from uncured leaves. The number of revertants was positively influenced by the duration of the curing. The effect of the duration of curing on the number of revertants was more pronounced with increasing CSC concentration. [Beitr. Tabakforsch. Int. 24 (2010) 72-77]

\section{ZUSAMMENFASSUNG}

Flue-curing ist ein Aufbereitungsprozess des Tabakblattes, der nach der Ernte erfolgt. Dieser Prozess greift sehr stark in die Chemie des Tabakblattes ein und damit auch in die chemischen Eigenschaften des Tabakrauches. Verschiedene Studien haben die gravierenden Veränderungen in der Tabakchemie beschrieben, die während des flue-curings stattfinden. Bisher ist aber nicht bekannt, wie flue-curing zu den Veränderungen in der biologischen Aktivität von Zigarettenrauchkondensat (CSC) beiträgt. In dieser Arbeit wurden während des flue-curing Prozesses über einen Zeitraum von zwölf Tagen Tabakblätter gesammelt. Diese wurden zu Zigaretten verarbeitet und abgeraucht, um das Zigarettenrauchkondensat zu erhalten. Die Bewertung der Mutagenität wurde mit Hilfe des bakteriellen reversen Mutationstests (Ames-Test) mit Salmonella typhimurium TA98 mit metabolischer Aktivierung durch S9 ausgeführt. CSC von Blättern, die den Curing-Prozess durchlaufen haben, zeigte eine signifikant höhere Mutagenität als das CSC von Blättern, die nicht den Curing-Prozess durchlaufen haben. Die Anzahl der Revertanten stieg mit der Dauer des Curing-Prozesses. Mit ansteigender CSC Konzentration war dieser Effekt der Dauer des Curing-Prozesses auf die Anzahl der Revertanten ausgeprägter. [Beitr. Tabakforsch. Int. 24 (2010) 72-77]

\section{RESUME}

Le séchage à l'air chaud est un procédé de conditionnement post-récolte qui affecte fortement la chimie de la feuille et conséquemment les propriétés chimiques de la fumée de tabac. Plusieurs études ont identifé les changements majeurs dans la chimie du tabac survenant lors du séchage. On ne sait pas comment il contribue à modifier la bioactivité des condensats de la fumée de cigarette (CFCs). Lors de notre étude, des feuilles de tabac ont été cueillies durant les douze jours de séchage. Elles ont été utilisées pour fabriquer des cigarettes qui ont été fumées pour générer des échantillons de CFC. L'évaluation de la mutagénicité a été faite en utilisant le test de Ames soit le test de mutation bactérienne inverse en utilisant la souche de Salmonella typhimurium TA98 en présence de l'activateur métabolique S9. Les CFCs de feuilles séchées 
étaient significativement plus mutagéniques que les CFC des feuilles non séchées. Le nombre de révertants était positivement influencé par la durée de séchage. L'effet de la durée de séchage sur le nombre de révertants était plus prononcé à des concentrations élevées de CFC. [Beitr. Tabakforsch. Int. 24 (2010) 72-77]

\section{INTRODUCTION}

In the tobacco leaf there are about 4000 known chemicals (1). The chemical composition of the leaf strongly affects the organoleptic, pharmacological and toxicological properties of tobacco smoke $(2,3)$. The physical and chemical properties of leaf tobacco depend on plant genetics, agricultural practices, soil type and nutrients, weather conditions, plant disease and pests, stalk position, harvesting and postharvesting procedures. A change in any of these factors can markedly alter the smoke quality $(4,5,6)$.

From tobacco harvesting to cigarette making, the leaves undergo important chemical changes, which mostly take place during the curing and aging process $(7,8)$. The curing process and its respective effects on tobacco chemistry are relatively well-described (9). Typically, tobaccos are classified on curing methods, which are used to process adequately the different tobacco variants and to produce different end-products $(5,10)$. In this project, the fluecuring of Virginia tobacco has been considered as it refers to most of the Canadian products.

While the process of flue-curing has been relatively welldescribed in terms of changes in leaf chemistry and product differentiation, less information is available on how the biological activity of the tobacco smoke evolves during the flue-curing of tobacco. However, the biological activity of tobacco smoke issued from fully cured tobacco has been studied using several toxicity assays. The Bacterial Reverse Mutation test (Ames test) which uses His- Salmonella typhimurium mutant strains, is the most widely used test in genetic toxicology worldwide. It has been extensively used to characterize cigarette smoke condensate toxicity, as well as the influence of many factors such as tobacco type, stalk position, sugar and nitrogen content of leaves, and others (11). Despite the rising of mammalian cell assays, the Ames test remained a common way for evaluating the relative toxicity of smoke condensate from different cigarette designs (12). Hence, the purpose of our study was to use the Ames test to assess the mutagenicity of smoke condensate of cigarettes containing tobacco collected during flue-curing. The study of the effects of flue-curing on tobacco smoke toxicity could contribute to further understanding how leaf components contribute to the toxicity of tobacco smoke.

\section{MATERIALS AND METHODS}

\section{Materials}

In August 2004, tobacco leaves were collected at SainteMélanie (QC, Canada). Day 0 leaves were collected directly in the field, and leaves from the following twelve days of flue-curing were collected in the curing barn. The leaves were then lyophilized, put in bags under vacuum and kept in a cold room at $4{ }^{\circ} \mathrm{C} \pm 1{ }^{\circ} \mathrm{C}$.

\section{Conditioning of tobaccos}

Lyophilized tobacco leaves were conditioned in a Hotpack temperature and humidity chamber (Heico Company, Warminster, PA $18974-2811$ ) at $22{ }^{\circ} \mathrm{C}$ and $80 \%$ relative humidity (R.H.) until the moisture content reached $13.5 \%$ $\pm 0.5 \%$. Then they were cut and sieved using Canadian Standard mesh sieves (W.S. Tyler, St. Catharines, Ontario L2R 7B6, Canada). Only the tobacco strips that passed through $1 / 4$ inch mesh sieve and that were retained on the mesh sieve no. 20 were respectively used for further experimental work. These strips represent more than $70 \%$ of the tobacco weight found in a commercial cigarette. Tobacco strip fractions were further conditioned until the moisture content reached $15 \% \pm 0.5 \%$ (minimum 4 days). The moisture content of tobacco was monitored by a moisture analyser (Denver Instrument Company, Model IR200, Denver, Colorado 80202). Appropriate moisture content ensured that the tobacco strips were not ground by the cigarette making machine.

\section{Preparation of cigarettes}

Cigarettes were prepared at a pressure drop of $132.25 \pm$ $3.59 \mathrm{~mm}$ Water Gauge (WG) using Player's filter tubes (ventilation: 0\%; permeability: 38 CORESTA Units (CU); total pressure drop: $53.3 \mathrm{~mm} \mathrm{WG}$ ) and conditioned at $22{ }^{\circ} \mathrm{C}$ and $60 \%$ R.H. for $48 \mathrm{~h}$ before smoking. Mainstream smoke yields of total particulate matter ('TPM'), nicotine, water and nicotine free dry particulate matter (NFDPM or 'tar') were determined by the smoking regime according to ISO methods 3308 (13), 4387 (14), 10362-1 (15) and 10315 (16).

\section{Collection of cigarette smoke condensates (CSC)}

Cigarettes from the different days of curing were smoked under ISO conditions $(35.0 \mathrm{~mL}$ puff volume, 2-sec duration, one puff/min) using a Borgwaldt RM 20 / CS rotary smoking machine. Cigarettes were smoked to $28 \mathrm{~mm}$ butt length and condensates were collected on 44-mm Cambridge filter pad. The condensates were then extracted from the pad on a Büchner funnel under vacuum, by adding drop-wise a specific volume of dimethylsulfoxide (DMSO). Cigarette Smoke Condensate (CSC) stock solutions at $15 \mathrm{mg} / \mathrm{mL}$ DMSO were aliquoted and kept in the dark at $-80^{\circ} \mathrm{C}$.

\section{Bacterial reverse mutation assay}

The mutagenicity of the CSC prepared from cigarettes containing tobacco cured for different days was assayed by conducting the Salmonella Reverse Mutation Assay as described by MARON and AMES (17). Assays were performed with the Salmonella typhimurium tester strain TA98 (Bruce N. Ames, Berkeley, CA). Exogenous metabolic activation was achieved by using a solution of $10 \% \mathrm{~S} 9$ in mix buffer (Molecular Toxicology Inc., Boone, NC 28607). This post mitochondrial fraction is prepared from the livers 
of rats treated with Aroclor 1254, an inducer of cytochrome P450. Each CSC resulting from the different days of curing was assayed in triplicate i.e. three different smoke condensates with three different bacterial cultures. Five doses were used: 100, 150, 200, 300 and $400 \mu \mathrm{g}$ TPM/plate. Each dose was plated in triplicate. The plates were incubated at $37^{\circ} \mathrm{C}$ for $48 \mathrm{~h}$. The number of His + revertant colonies per plate was determined with a colony counter (Autocount ${ }^{\mathrm{TM}}$, Dynatech Laboratories Inc., Chantilly, VA 22021). DMSO (dimethyl sulfoxide) solvent control and appropriate positive control substance (benzo $[a]$ pyrene $(\mathrm{B}[a] \mathrm{P}), 1.0$ $\mu \mathrm{g} /$ plate) were assayed in all experiments.

\section{Statistical analysis}

In order to determine the impact of the curing time on the mutagenicity of CSC tested at different doses, toxicological data obtained from the Ames test were analysed by using a quadratic regression model. Analyses were performed using the R software (18). The number of revertants, excluding solvent background was used as the response variable. The concentration of CSC (i.e., dose expressed as $\mu \mathrm{g}$ of $\mathrm{TPM} /$ plate) and the number of days of curing were used as independent quantitative variables. The quadratic effects of these variables as well as their interaction were also included in the statistical model, while repetitions were treated as a random factor (19). Homogeneity of variance of the residuals was originally assumed. However, as it was observed that the variance of the residuals increased with the exposure, a second model including the same effects but assuming that the residual variability linearly increases with dose was fitted. The validity of this assumption was verified before interpreting the results.

\section{RESULTS}

\section{Total particulate matter, 'tar' and nicotine of test cigarettes}

In general, the levels of TPM, 'tar' and nicotine of cigarettes made with tobacco cured for different days increased as curing progressed. At the end of curing, the above numbers were comparable to a commercial product of the same 'tar' level (Table 1).

\section{Bacterial reverse mutation assay}

The mutagenicity of smoke condensates obtained from cigarettes made with Virginia tobaccos flue-cured for twelve days increased significantly during this period (Table 2, Figure 1).

Statistical modeling of the data detected both significant positive linear and quadratic effect of the CSC dose on the number of revertants (linear: $p \leq 0.001$, quadratic: $p=0.002$ ). The duration of the curing was found to interact with the concentration of the condensate used i.e. the effect of the curing was significantly more pronounced at higher CSC doses ( $p \leq 0.001)$ (Table 3$)$.
Table 1. Total particulate matter (TPM), 'tar' (nicotine free dry particulate matter (NFDPM)) and nicotine of test cigarettes compared to a commercial product. Cigarettes made with tobacco cured for different days.

\begin{tabular}{l|c|c|c|c}
\hline $\begin{array}{l}\text { Curing } \\
\text { days }\end{array}$ & $\begin{array}{c}\text { TPM } \\
\mathrm{mg} / \mathrm{cig}\end{array}$ & $\begin{array}{c}\text { NFDPM } \\
\mathrm{mg} / \mathrm{cig}\end{array}$ & $\begin{array}{c}\mathrm{H}_{2} \mathrm{O} \\
\text { per } \mathrm{mg} \\
\text { TPM }\end{array}$ & $\begin{array}{c}\text { Nicotine } \\
\text { per } \mathrm{mg} \\
\mathrm{TPM}\end{array}$ \\
\hline 0 day & 8.2 & 6.3 & 0.172 & 0.054 \\
3 days & 7.6 & 5.9 & 0.160 & 0.057 \\
6 days & 11.1 & 8.5 & 0.168 & 0.067 \\
9 days & 14.9 & 11.8 & 0.132 & 0.078 \\
$\begin{array}{l}12 \text { days } \\
\begin{array}{l}\text { Control } \\
\text { cigarette }\end{array}\end{array}$ & 15.3 & 11.9 & 0.152 & 0.070 \\
\hline
\end{tabular}

\section{DISCUSSION}

Flue-curing of tobacco affects its chemical and physical properties and ultimately the smoke composition. The first stage of flue-curing is the yellowing (day 0 to 5) (20) and consists of the senescence of the leaves characterized by the decomposition of green chlorophyll which allows yellow carotene and xanthophyll pigments to be visible. The second stage is the colour fixing (day $6 \pm 1$ day) during which the temperature is gradually increased to $40-50{ }^{\circ} \mathrm{C}$ while the relative humidity is decreased until complete desiccation. During the stem drying stage (day 7 to 12 ), temperature is increased up to $70-75^{\circ} \mathrm{C}$.

In this study, the mutagenicity of the smoke generated from cigarettes prepared with tobacco flue-cured for up to twelve days was determined by using the Ames test with S. typhimurium TA98 strain. The results of the Ames test demonstrated that the CSC generated from cigarettes containing flue-cured tobacco were significantly more mutagenic than CSC generated from cigarettes containing green tobacco (day 0: uncured).

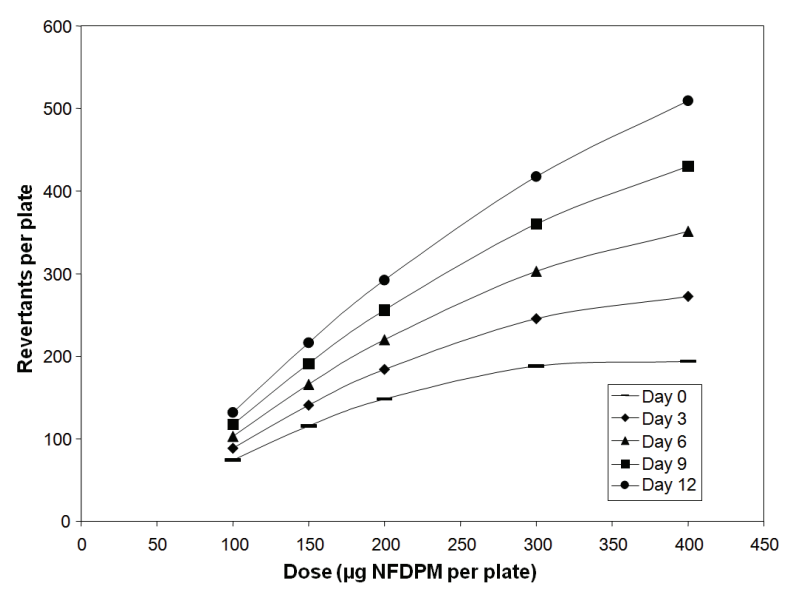

Figure 1. Predicted mutagenicity (revertants of $S$. typhimurium TA98 +S9) of various doses of smoke condensates generated from cigarettes containing Virginia tobacco flue-cured for up to twelve days. Each CSC resulting from the different days of curing was assayed in triplicate i.e., three different smoke condensates with three different bacterial cultures. 
Table 2. Average revertant number (Salmonella typhimurium strain TA 98 Histidine Plus (His ${ }^{+}$) and standard deviation (S.D.) of the samples at different total particulate matter (TPM) and nicotine free dry particulate matter (NFDPM) doses per plate adjusted for the background counts (DMSO solvent).

\begin{tabular}{|c|c|c|c|c|c|}
\hline $\begin{array}{l}\text { Dose } \\
(\mu \mathrm{g} \text { TPM/plate) }\end{array}$ & $\begin{array}{c}\text { Samples } \\
\text { (days of curing) }\end{array}$ & $\begin{array}{l}\text { No. revertants } \\
\text { His }^{+}\end{array}$ & $\begin{array}{l}\text { No. revertants } \\
\mathrm{His}^{+} \text {(-DMSO) }\end{array}$ & S.D. & $\begin{array}{c}\text { Dose } \\
(\mu \mathrm{g} \text { NFDPM/plate })\end{array}$ \\
\hline 0 & 0 & 20 & $\ldots$ & $\ldots$ & $\ldots$ \\
\hline 100 & 0 & 71 & 51 & 3.1 & 76.8 \\
\hline 150 & 0 & 105 & 85 & 8.4 & 115.2 \\
\hline 200 & 0 & 132 & 112 & 16.5 & 153.7 \\
\hline 300 & 0 & 179 & 160 & 18.9 & 230.5 \\
\hline 400 & 0 & 216 & 197 & 45.5 & 307.3 \\
\hline 0 & 3 & 20 & $\ldots$ & $\ldots$ & $\ldots$ \\
\hline 100 & 3 & 99 & 80 & 6.3 & 77.6 \\
\hline 150 & 3 & 144 & 124 & 4.4 & 116.4 \\
\hline 200 & 3 & 185 & 165 & 21.5 & 155.3 \\
\hline 300 & 3 & 255 & 236 & 8.2 & 232.9 \\
\hline 400 & 3 & 307 & 287 & 29.8 & 310.5 \\
\hline 0 & 6 & 20 & $\ldots$ & $\ldots$ & $\ldots$ \\
\hline 100 & 6 & 73 & 54 & 9.0 & 76.6 \\
\hline 150 & 6 & 114 & 95 & 20.9 & 114.9 \\
\hline 200 & 6 & 156 & 137 & 16.7 & 153.2 \\
\hline 300 & 6 & 222 & 202 & 7.8 & 229.7 \\
\hline 400 & 6 & 276 & 256 & 33.1 & 306.3 \\
\hline 0 & 9 & 20 & $\ldots$ & $\ldots$ & $\ldots$ \\
\hline 100 & 9 & 111 & 92 & 7.3 & 79.2 \\
\hline 150 & 9 & 168 & 149 & 10.2 & 118.8 \\
\hline 200 & 9 & 239 & 220 & 9.2 & 158.4 \\
\hline 300 & 9 & 330 & 311 & 5.0 & 237.6 \\
\hline 400 & 9 & 390 & 370 & 12.1 & 316.8 \\
\hline 0 & 12 & 20 & $\ldots$ & $\ldots$ & $\ldots$ \\
\hline 100 & 12 & 111 & 92 & 13.3 & 77.8 \\
\hline 150 & 12 & 173 & 154 & 7.4 & 116.7 \\
\hline 200 & 12 & 255 & 236 & 21.9 & 155.6 \\
\hline 300 & 12 & 383 & 364 & 25.9 & 233.3 \\
\hline 400 & 12 & 449 & 429 & 52.0 & 311.1 \\
\hline 0 & control & 34 & $\ldots$ & $\ldots$ & $\ldots$ \\
\hline 100 & control & 192 & 159 & 18.2 & 78.2 \\
\hline 150 & control & 270 & 237 & 14.4 & 117.3 \\
\hline 200 & control & 342 & 308 & 30.2 & 156.3 \\
\hline 300 & control & 448 & 415 & 13.7 & 234.5 \\
\hline 400 & control & 533 & 500 & 38.2 & 312.7 \\
\hline
\end{tabular}

Major chemical and biochemical changes would begin during the yellowing stage and continue through the early phase of color fixing (21). Among the changes occurring during the two first phases of flue-curing, there are the hydrolysis of proteins into free amino acids, hydrolysis of starch into reducing sugars and the reaction of the amino acids with sugars to form Amadori compounds (7, 9, 22, $23,24,25,26)$. The pattern of changes of soluble proteins in tobacco leaf during curing has been illustrated by using polyacrylamide disc gel electrophoresis (27): out of thirteen anodic protein bands visualised at the beginning of curing, nine were not anymore visible at the end of curing. Soluble protein fractions from tobacco leaves before and after curing were compared on Sephadex G-200 or G-75 chromatography and by immunological experiments: the amount of larger molecular weight proteins diminished during curing and smaller molecular weight proteins accumulated (28). When pyrolysed, tobacco proteins, peptides and amino acids were shown to contribute to the mutagenicity as assessed by the Ames assay $(29,30)$. Thus, these pyrolysis products could increase the toxicity of condensates prepared from cigarettes containing tobacco harvested during the first two stages of the flue-curing process. Indeed, a study showed that the removal of protein reduced the toxicity of CSC of about $80 \%$ in the $S$. typhimurium TA98 strain (31). Consequently, the increase in CSC mutagenicity during the flue-curing process could then be linked to the important changes in leaf chemistry taking place during the yellowing and colour-fixing stages. At the end of the curing process, tobacco has relatively low 
Table 3. Model parameters (variables) used to determine the impact of the curing time on the mutagenicity of cigarette smoke condensates tested at different doses.

\begin{tabular}{l|c|c|c|c}
\hline Variables & Value & Standard error & Degree of freedom & $t$-value \\
\hline Intercept & -34.178 & 17.252 & 68 & -1.981 \\
Dose & 1.254 & 0.203 & 68 & 6.171 \\
Curing duration & -2.352 & 1.397 & 68 & -1.683 \\
Dose x dose & -0.001 & 0.000 & 68 & -3.246 \\
Dose x curing duration & 0.071 & 0.008 & 68 & 8.168 \\
\hline
\end{tabular}

contents of proteins and amino acids (21), but we observed a continuous increase in CSC mutagenicity. Although the stem drying stage of flue-curing would not apparently affect the leaf chemistry as very little chemical changes occur in that stage except for reduction in moisture content (21), an increase in mutagenicity was observed. During air curing, it has been suggested that the activities of enzymes initially present in green tobacco are responsible for the major chemical changes described above (32). It is not known if these enzymes are active during stem drying. Following hydrolysis of starch, the level of free reducing sugars increased by $9 \%$ (water- and sand-free basis; (7)). Reducing sugars can react in vitro with DNA and induce mutations in bacterial and mammalian cells (33). Following hydrolysis of proteins and starch, L-amino acids and sugars (e.g. D-glucose) react to form Amadori compounds. The latter are direct-acting mutagens (34). Their amount increased and then decreased during four years of aging (35). To our knowledge, the kinetics of the Amadori compounds during curing is not documented. Another hypothesis is that curing of tobacco could lead to the formation of toxic glycation products i.e. reactive cross-linking moieties formed from the reaction of reducing sugars and the amino groups of proteins (Amadori compounds), lipids and nucleic acids (33). Thus, the accumulation of reducing sugars and possibly of Amadori compounds and other advanced glycation end products (AGEs) might contribute to the continuous increase of mutagenicity during the final drying stage of curing.

\section{ACKNOWLEDGMENTS}

The authors are grateful to Denis Coulombe for providing tobacco leaves along the flue-curing process, France Côté for her assistance in sample handling, Mathieu Sauvé and Yves DeGrandpré for their advice on tobacco reconditioning.

\section{REFERENCES}

1. Rodgman, A. and T.A. Perfetti: The Chemical Components of Tobacco and Tobacco Smoke; CRC press, Boca Raton, FL, 2008.

2. Leffingwell J.C. and D. Leffingwell: Chemical and sensory aspects of tobacco flavour; Rec. Adv. Tob. Sci. 14 (1988) 169-218.

3. Tso T.C.: Production, physiology and biochemistry of tobacco plant; Ideals Inc., Beltsville, MD, 1990.

4. Wynder E.L. and D. Hoffmann: Tobacco and tobacco smoke - Studies in experimental carcinogenesis; Academic Press, New York, 1967.

5. Akehurst, B.C.: Tobacco. Tropical Agriculture Series; Longman Group Ltd, U.K., 1981.

6. Leffingwell, J.C.: Chemical constituents of tobacco leaf and differences among tobacco types; Leffingwell Reports 1 (2001) 1-56.

7. Bacon, C.W., R. Wenger, and J.F. Bullock: Chemical changes in tobacco during flue-curing; Ind. Eng. Chem. Res. 44 (1952) 292-296.

8. Huber, G.L.: Physical, chemical, and biological properties of tobacco, cigarette smoke, and other tobacco products; Semin. Respir. Med. 10 (1989) 297-332.

9. Leffingwell, J.C.: Nitrogen components of leaf and their relationship to smoking quality and aroma; Rec. Adv. Tob. Sci. 2 (1976) 1-31.

10. Johnstone, R.A.W. and J.R. Plimmer: The chemical constituents of tobacco and tobacco smoke; Chem. Rev. 59 (1959) 885-936.

11. DeMarini, D.M.: Genotoxicity of tobacco smoke and tobacco smoke condensate; Mutat. Res. 114 (1983) 59-89.

12. Andreoli, C., D. Gigante, and A. Nunziata: A review of in vitro methods to assess the biological activity of tobacco smoke with the aim of reducing the toxicity of smoke; Toxicol. In Vitro 17 (2003) 587-94.

13. ISO 3308: Routine analytical cigarette smoking machine - Definition and standard conditions: International Organisation for Standardization, Geneva, 2000.

14. ISO 4387: Cigarettes - Determination of total and nicotine free dry particulate matter using a routine analytical smoking machine: International Organisation for Standardization, Geneva, 2000.

15. ISO 10362-1: Cigarettes - Determination of water in smoke condensates - Part 1: Gas-chromatographic method: International Organisation for Standardization, Geneva, 1999.

16. ISO 10315: Methods for chemical analysis of tobacco and tobacco products. Determination of nicotine smoke condensate of cigarettes (gas-chromatographic method): International Organisation for Standardization, Geneva, 1991

17. Maron, D.M. and B.N. Ames: Revised methods for the Salmonella mutagenicity test; Mutat. Res. 113 (1983) 173-215.

18. R Development Core Team: R: A Language and Environment for Statistical Computing; R Foundation for Statistical Computing, Vienna, Austria. ISBN 3-900051-07-0, URL http://www.R-project.org/; 
2008.

19. Pinheiro, J.C. and D.M. Bates: Mixed-Effects Models in S and S-Plus; Springer-Verlag, New York, 2000.

20. Walker E.K. and D.A. Stier: Curing flue-cured tobacco in Canada; Agriculture Canada Publication. 1312/E, 1987.

21. Cousins, A.R.: Nitrogen complexes in tobacco; Chem. Ind. (1972) 19-20.

22. Green C.R.: Relationship of leaf composition to smoke composition. In: Proceedings of American Chemical Society Symposium. Recent Advances in the Chemical Composition of Tobacco and Tobacco Smoke. The 173rd American Chem. Society Meeting Agric. Food Chem. Division, New Orleans, LA, USA, 1977, pp. 426-471.

23. Schmeltz I. and D. Hoffmann: Nitrogen-Containing Compounds in Tobacco and Tobacco Smoke; Chem. Rev. 77 (1977) 295-311

24. Long, R.C. and J.A. Weybrew: Major chemical changes during senescence and curing; Rec. Adv. Tob. Sci. 7 (1981) 40-74.

25. Weeks W.W.: Relationships between leaf chemistry and organoleptic properties of tobacco smoke; in: Tobacco; Production, Chemistry and Technology, edited by D.L. Davis and M.T. Nielsen, Blackwell Science, Oxford, UK., 1999, pp. 304-312.

26. Matsumoto, T., D. Yoshida, S. Mizusaki, and H.Okamoto: Mutagenic activity of amino acid pyrolysates in Salmonella typhimurium TA98; Mutat. Res. 48 (1977) 279-286.

27. Sheen, S. J. and B.I. Townes: Electrophoretic patterns of soluble proteins in tobacco leaf during curing; Beiträge zur Tabakforschung 5 (1970) 285-289.

28. Kawashima, N., A. Imai, and E. Tamaki: Studies on protein metabolism in higher plants IV. Changes in protein components in detached leaves of tobacco; Plant. Cell. Physiol. 8 (1967) 595-604.

29. Matsumoto, T., D. Yoshida, S. Mizusaki S., and H. Okamoto: Mutagenicities of the pyrolysates of peptides and proteins; Mutat. Res. 56 (1978) 281-288.

30. Clapp, W.L., B.S. Fagg, and C.J. Smith: Reduction in Ames Salmonella mutagenicity of cigarette mainstream smoke condensate by tobacco protein removal; Mutat. Res. 446 (1999) 167-174.

31. Peele, D.M., D.A. Danehower, and G.D. Goins: Chemical and biochemical changes during flue-curing of tobacco; Rec. Adv. Tob. Sci. 21 (1995) 81-133.

32. Zelitch, I. and M. Zucker: Changes in Oxidative Enzyme Activity During the Curing of Connecticut Shade Tobacco; Plant. Physiol. 33 (1958) 151-155.

33. Cerami, C., H. Founds, I. Nicholl, T. Mitsuhashi, D. Giordano, S. Vanpatten, A. Lee, Y. Al-Abed, H. Vlassara, R. Bucala, and A. Cerami: Tobacco smoke is a source of toxic reactive glycation products; Proc. Natl. Acad. Sci. USA 94 (1997) 13915-13920.

34. Bartsch, H., H. Oshima, B. Pignatelli, C. Malaveille, and $\mathrm{M}$. Friesen: Nitrite-reactive phenols present in smoked foods and amino-sugars formed by the Maillard Reaction as precursors of genotoxic arenediazonium ions or nitroso compounds; in: Mutagens in Food: Detection and Prevention, edited by H. Hayatsu, CRC Press , Boca Raton, FL, 1990, pp. 87-100.

35. Noguchi, M., Y Satoh, K Nishida, S. Andoh, and E. Tamaki: Studies on storage of leaf tobacco part. Changes in the content of aminosugar compounds during aging; Agri. Biol. Chem. 35 (1977) 65-70.

Address for correspondence:

André Morin

Imperial Tobacco Canada Limited, 3711 St-Antoine Street West, Montreal, QC, H4C 3P6, Canada E-mail: amorin@itl.ca 